\title{
Causality Analysis of Non-oil Tax Component of Government Revenue, Company Income and Transaction Taxes: Evidence from a Third World Developing Economy
}

\author{
Orits Frank Ebiaghan, Edirin Jeroh*, Abel Oghenevwoke Ideh \\ Department of Accounting and Finance, Delta State University, Abraka, Nigeria
}

Received June 26, 2021; Revised October 2, 2021; Accepted October 21, 2021

\begin{abstract}
Cite This Paper in the following Citation Styles
(a): [1] Orits Frank Ebiaghan, Edirin Jeroh, Abel Oghenevwoke Ideh, "Causality Analysis of Non-oil Tax Component of Government Revenue, Company Income and Transaction Taxes: Evidence from a Third World Developing Economy,"Universal Journal of Accounting and Finance, Vol. 9, No. 6, pp. 1355-1365, 2021. DOI: 10.13189/ujaf.2021.090614.
\end{abstract}

(b): Orits Frank Ebiaghan, Edirin Jeroh, Abel Oghenevwoke Ideh (2021).Causality Analysis of Non-oil Tax Component of Government Revenue, Company Income and Transaction Taxes: Evidence from a Third World Developing Economy. Universal Journal of Accounting and Finance, 9(6), 1355-1365. DOI: 10.13189/ujaf.2021.090614.

Copyright $\odot 2021$ by authors, all rights reserved. Authors agree that this article remains permanently open access under the terms of the Creative Commons Attribution License 4.0 International License

\begin{abstract}
Overtly, the colossal infrastructural deficit occasioned by the ever increasing population of Nigeria requires sizeable revenue strings if they must be copiously addressed. Largely, the country has over time relied on oil revenue to carry-out her sacred duty of welfare and security provision along with efforts targeted at guaranteeing freedom of her citizenry amongst others. With the recent global drop in oil prices, there has been a general call for government to reinforce other channels of revenue generation so that the country can weather the tides of economic turmoil. This however calls for an understanding of the interrelatedness of various components of accruable revenue to the government through a causality study of such revenue components. This study thus focuses on a causality analysis of non-oil tax component of government revenue, company income and transaction taxes by obtaining empirical evidence from a third world developing economy - Nigeria. Time series data for 15 years were analysed based on the study's intent and with the use of relevant statistics like the unit root tests, chow test, granger causality test, least square and auto regressive regression analysis. Our study's outcome proved that while federally generated revenue proved to have been significantly improved by revenue from income taxes and stamp duties, the tax policies and their subsequent
\end{abstract}

amendments could not exert significant influence on non-oil tax revenue of government during the period. On this note, we recommend the need for effective policy pertaining to Stamp Duties and Companies' Income Tax (CIT) along with a marginal reduction in tax holidays of companies to the extent that the Stamp Duties' Act (SDA) is fully enforced/implemented vis-à-vis strict penalties for non-compliance. Outcome from this research has policy implications which stand to benefit regulatory bodies/policy makers, tax consultants, academics and key stakeholders as it presents key issues relating to CIT, SDA, and non-oil revenue of Nigeria's government.

Keywords Taxes, Government Revenue, Tax Holiday, Ad Valorem, Developing Nations, Transaction Tax, Nigeria

\section{Introduction}

Adequate provision for the security, welfare and freedom of the citizenry is one sacred duty of governments, the world over. This sacred duty presumably forms the bedrock for sustainable 
socio-economic development and growth. Soubbotina [24] alluded to this fact by asserting that the quality of life of citizens of a state forms the basis of any development objective, which should be geared towards improved healthcare delivery, clean air, access to education, employment opportunities, safe drinking water and security of lives and properties. The availability and access to these amenities and infrastructures aptly determines the people's quality of life or standard of living.

Worth mentioning is the fact that governments' ability to provide the platform and atmosphere for sustainable socio-economic development requires huge capital investments. Specifically, Nigeria, being a third world developing economy requires huge revenue to make provision for the colossal infrastructural deficit occasioned by her ever-increasing population. Arguably, an efficient and/or effective tax system can possibly help governments in the area of generating sufficient revenue that would be used in catering for their projected expenditures on infrastructural development and satisfy the basic needs of their citizenry. This is why several countries of the world had relied heavily on taxation in order to generate the much needed revenue to cater for their respective developmental needs. In fact, studies have pointed that tax revenue guarantees a relatively stable and predictable stream of revenue to finance people-focused developmental projects $[13,22,6]$.

As noted in the literature, tax payments partly represent prices paid for presumably living in organised/orderly societies, and constitute bulk of government revenue in Sub-Saharan Africa [3]. Notwithstanding, taxation systems vary across countries due to divergent socio-political and economic ideologies and aspirations at any particular time. This accounts for why tax systems in a country like Nigeria is seen as constantly evolving to meet the developmental needs of the federation.

Nigeria is abundantly endowed with crude oil in addition to other solid mineral resources, but sadly, successive governments exhibited the tendency to depend solely on oil revenue for funding developmental projects. However, as the population expanded and government responsibility increased, it became evident that over reliance on non-tax revenue (revenue from oil and other natural resources) was unsustainable given fluctuations in production capacity occasioned by militant activities in the Niger-Delta and global oil price shocks. To tackle this revenue shortfall, government resorted to massive borrowing in order to fund the huge budget deficits thus plunging the economy into debt crises and fiscal imbalance $[4,28]$. This has so far generated strident calls from interested stakeholders and the organized private sector who believes that government at all levels may need to explore alternative sources of generating revenue beyond oil.

To boost its non-oil revenue base, the Nigerian government since 1939 has been enacting various tax ordinances' and laws to compel individuals and corporations to pay part of their earnings as tax. But given the twin challenges of tax evasion and avoidance, there is the need to ascertain if these tax measures have significantly contributed to federal government non-oil tax revenue. This forms the main thrust of this paper. In the light of the forgoing therefore, this research is aimed at:

(a) ascertaining the extent to which Company Income tax (CIT) have significantly contributed to federal government non-oil tax revenue in Nigeria.

(b) ascertaining the extent to which tax revenues from Stamp Duties have significantly contributed to federal government non-oil tax Revenue in Nigeria.

\section{Conceptual Review}

\subsection{Evolution of CIT in Nigeria}

Taxation has so far been described as a fiscal tool deployed by public authorities for public purposes. It depicts systems of raising compulsory levies by governments through well-defined fiscal tools with individuals and corporate entities as major targets/contributors [25]. Nightingale [16] described tax as contributions compulsorily imposed by governments. Though individual tax payers may not receive commensurate return vis a vis their contributions, no doubt, they ultimately gain from living in a relatively healthy, educated and secured society.

Historically the first known taxes on companies were imposed under the CIT ordinance 1939. This was said to have been consolidated with personal income tax (PIT) in 1940 under the tax ordinance (income tax) of 1940. As indicated by the ordinance, CIT was imposed upon any "person" and this expression was defined to include a company, under the 1940 ordinance, the tax was progressive and individuals with chargeable income exceeding fifty pounds and companies paid the same rate, which was 3 pence on every pound of the first $€ 200$ and progressively to 10 shillings for every pound exceeding $€ 10,000$. The ordinance further reiterated that dividends were deemed to have been paid to various shareholders net of tax deductions, as such should not suffer any more $\operatorname{tax}(\mathrm{es})$.

Noteworthy, three years after the initial enactment of the tax ordinance of 1940, another tax ordinance of 1943 was enacted specifically to consolidate on, and possibly amend the then 1940 ordinance. Notably, the key modification to the then 1940 ordinance as found in the 1943 ordinance hinged on issues relating to penalties. For the first time in the development of income tax laws in Nigeria, failures relating to overtly furnishing returns, or keeping relevant/required records were tagged as criminal. Similarly, acts of furnishing incorrect returns through 
omissions or understatement of income were made criminal offences with option of fine or imprisonment or both.

No doubt, Nigeria's current tax systems has their roots in the Raiseman fiscal commission's recommendation that jurisdiction over CIT should be exclusive to Nigeria's central government so that the states except for certain uniform principles, should have jurisdiction over PIT.

Following the foray of the military into political governance between 1966 to September 1979, the CIT Decree (CITD) No.28 of 1979 was enacted to replace the CIT Act (CITA) of 1961 which originally amended the initially amended ordinance of 1943. This decree is a codification of all CIT enactments since 1961.Beginning from 1979, several amendments to CITD No.28.were made through several Acts/Decrees/Enactments (where applicable). As of 2020, the Finance Act of 2019 was signed into Law to amend several provisions of the existing tax laws in the country.

\subsection{Company Income Tax (CIT)}

These taxes are practically levied on profits of registered body corporate in Nigeria. By law, companies involved in petroleum operations are not subjected to CIT since they are assessed under a separate tax law. Primarily, companies operate with the aim of making profit; whereas, in the course of running the business, they are expected to enjoy essential services from the government construction and maintenance of road networks, electricity and telecommunication facilities amongst others. The government on their part, support in the development of human resources through the establishment and maintenance of universities, colleges and other educational institutions. It therefore becomes imperative for companies to pay taxes which represent a key element of the contribution that they make to their respective economies as they operate [1]. In order to practically monitor and enforce compliance, Nigeria was able to promulgate CITA in 1979 (with subsequent amendments), establish the Federal Board of Inland Revenue and most recently, the signing of the Finance Act of 2019 [11].

\subsection{Stamp Duty}

Stamp duties are transaction taxes whose administration is jointly enforced by appropriate authorities established by government at either the state or federal level based on the nature or type of document involved. Stamp duties are revenue generation channels for concerned governments and are effectively levied on documents and/or instruments. Specifically, the chargeable rates of stamp duties depend basically on how identifiable taxable documents are classified. Thus, while some documents are chargeable on flat rate basis, others may be assessed on ad-valorem basis [23]. Chargeable documents include marriage certificates, commissions, receipts cheques, documentations of transactions on real estates etc.

As a requirement of the law, any such documents to be tendered or admissible as evidence in any competent court of jurisdiction must fulfil the requirements of the Act establishing stamp duties in Nigeria. Stamp duty, believed to have originated in Spain, was introduced to other parts of the world around the $16^{\text {th }}$ century (the Netherlands 1620s; France - 1651; Denmark - 1657; England - 1694).

Nigeria introduced Stamp duty in the 1890s, although, it officially got legal backing on April $1^{\text {st }}, 1939$, by the endorsement of the Stamp Duties Act by Parliament. Since then, the law has had several amendments with the most recent, being the specifications in the Finance Act of 2019 which according to Jeroh [11] increased chargeable stamp duties on electronic transactions and receipts to $\$ 50$ (fifty nairas) only once the value of such receipts/transaction amounts to at least, $\$ 10,000$ (ten thousand nairas) only.

Section 4 of the Stamp duties Act, LFN, 2004 (as amended) states in clear terms, the competent authorities charged with the responsibility of imposing charges and collect stamp duties. While the federal government (FGN) that has the authority to charge/impose and collect stamp duties on documents/instruments relating to companies versus other companies and companies versus individuals, the law empowers state governments to collect such duties (stamp duties) on documents/instruments executed between and among individuals.

\subsection{The Trajectory of CIT and Stamp Duty (SD) Contributions to Total Non-oil Revenue in Nigeria}

Table 1 depicts the growth trajectory of the contributions of CIT and SD to total non-oil revenue in Nigeria, from $2011-2017$. As seen in the table, non- oil tax increased marginally from $\$ 153.4500$ billion to \$159.9208 billion between 2011 and 2012 representing $1.24 \%$ increase year-on- year. However, there was a marked improvement beginning from 2013 as revenue rose from $\$ 174.7771$ billion in 2013, to 182.1231 billion by 2014. Lucidly, the period 2015 through 2017 witnessed very significant improvement in the percentage (\%) contribution as it increased from $33.89 \%$ in 2015 to $38.56 \%$ in 2016 and $45.79 \%$ in 2017 with year on year increment of $7.23 \%$ between $2016-2017$. Equally, of the two variants of non-oil tax, CIT has been contributing significantly to the total non-oil tax; this could be attributed to government tax reforms coupled with perceived committed implementation and possible enforcement of tax legislation aimed at ensuring that companies in operation pay tax commensurate with their earnings. 
Table 1. Analysis of the Contributions of CIT and SD to Federal Government Total Non-oil Tax revenue

\begin{tabular}{|c|c|c|c|}
\hline \multicolumn{4}{|c|}{ TAX REVENUE-COLLECTION BY TYPES. } \\
\hline Years & Non- oil Tax & $\begin{array}{c}\text { Actual Collections } \\
\text { (¥'billions) }\end{array}$ & $\begin{array}{c}\text { \% Contribution to the total } \\
\text { collection }\end{array}$ \\
\hline \multirow[t]{3}{*}{2011} & CIT & 151.3937 & 11.91 \\
\hline & Stamp Duty & 1.9471 & 0.15 \\
\hline & Sub Total & 153.4500 & 12.07 \\
\hline \multirow[t]{3}{*}{2012} & CIT & 156.4812 & 13.02 \\
\hline & Stamp Duty & 2.0403 & 0.17 \\
\hline & Sub Total & 159.9208 & 13.31 \\
\hline \multirow[t]{3}{*}{2013} & CIT & 167.8149 & 16.67 \\
\hline & Stamp Duty & 2.1549 & 0.21 \\
\hline & Sub Total & 174.7771 & 17.36 \\
\hline \multirow[t]{3}{*}{2014} & CIT & 176.8439 & 17.62 \\
\hline & Stamp Duty & 3.8889 & 0.38 \\
\hline & Sub Total & 182.1231 & 18.14 \\
\hline \multirow[t]{3}{*}{2015} & CIT & 265.3192 & 33.55 \\
\hline & Stamp Duty & 1.4468 & 0.18 \\
\hline & Sub Total & 267.9669 & 33.89 \\
\hline \multirow[t]{3}{*}{2016} & CIT & 933.5373 & 36.22 \\
\hline & Stamp Duty & 5.9030 & 2.34 \\
\hline & Sub Total & $1,124.7218$ & 38.56 \\
\hline \multirow[t]{3}{*}{2017} & CIT & 1215.9568 & 42.34 \\
\hline & Stamp Duty & 8.9335 & 3.45 \\
\hline & Sub Total & $1,262.0092$ & 45.79 \\
\hline
\end{tabular}

Source: FIRS: Planning, Research and Statistics Department, 2018.

\section{Empirical Review}

Extant documentations on the presumed impact of taxation on federally generated revenue is replete with several studies that seeks to measure the contributions of CIT and stamp duty to non-oil tax revenue in Nigeria. Attempts were consciously made in this section to review related prior studies. In a Nigerian study, Adeusi, Uniamikogbo, Erah \& Aggreh [2] probed the presumed causal link between non-oil income and economic growth. Four (4) proxies for non-oil income (VAT, CIT, PIT, and Excise Duties) were examined, whereas; GDP was utilized as the surrogate (proxy) for economic growth. These data (secondary) were gleaned from FIRS Statistical bulletin for 2018 and the NBS annual report of 2019. The data spanned from 1994-2018. Additionally, the OLS regression technique was applied to assess the causal link between growth and revenue (non-oil income) Findings indicates that secondary taxes (VAT and Excise Duties) exerted significant positive influence on Nigeria's growth economically when compared to direct taxes (CIT and PIT). Equally, direct taxes exerted long run adverse shock on economic growth; thus necessitating the recommendation that government should control the country's tax regimes by adopting and strategically implementing transparent and unassuming systems of tax legislations with a view to avoiding tax elusion while sustaining moderate tax avoidance where absolute riddance of associated avoidance practices cannot be guaranteed.

Olaoye and Adebayo [18] assessed the effect which Nigeria's BEPS (Base-Erosion-and-Profit-Shifting) has on revenue generation. By adopting ex post-facto design, efforts were made to collect quarterly data on GDP and tax revenue from the statistical bulletin and annual reports of the country's central bank (CBN), exchange commission (SEC) and Inland Revenue Service (FIRS) respectively. The data were for 5 years (2013-2017) covering eighteen quarters. Simple regression with paired t-test alongside mean and other relevant statistics were computed and formed the basis of hypotheses testing. Results showed that revenue generated from tax after the adoption of BEPS significantly differs from what was gotten prior to BEPS adoption. Revenue from taxes was found to have exerted significant effect on Nigeria's economy. The conclusion was that BEPS exerts significant positive effect on Nigeria's economic growth.

In a given study, Ofoegbu, Akwu and Oliver [17] examined how tax revenue may possibly affect economic development (as proxied by Human Development Index HDI) and Gross Domestic Product (GDP). The study 
focused on Nigeria and annual data (time series) from 2005 to 2014 were used to estimate a linear model expressing the linkage between government revenue through tax and HDI. Findings revealed that estimating the effect of tax revenue on economic development using HDI presents a positive and significant relationship in comparison with GDP. They concluded that formulation of any policy or enactment on taxation in the country should take cognizance of, and emphasize more HDI rather than GDP. Similarly, in a related study, Baghebo [5], examines how taxation and government expenditure affects growth and economic development in Nigeria, by appraising the interventions of government on the economy through fiscal and monetary policies. While observing that corruption and mismanagement constitute one major hindrance to the effective channelling of revenue accrued from taxation and other sources, the study however advocated a more transparent, free and credible electoral process that may encourage the emergence of credible government officials with genuine interests in national development.

Iyehen and Mieseigha [10] examine taxation as a concept and instrument for growth in Nigeria's economy. Utilizing annual data from 1980 - 2013 (time series), a linear model linking CIT, VAT and GDP (proxy for growth in Nigeria's economy) was estimated using the Ordinary Least Square (OLS) technique. The empirical findings suggest that the hypothesized nexus among CIT, VAT and GDP indeed exist in the Nigerian context. The conclusion reached was that concerted efforts should be made on the part of tax administrators to avoid related sharp practices like tax evasion, avoidance, etc with a view to increasing growth consequent on an increase in federally generated revenue through tax in the country.

Etale and Bingilar [8] appraised the influence which direct taxes may have on Nigeria`s growth. Time series panel data for 10 years (2005 to 2014) were compiled and analysis was done using the OLS technique. The research outcome indicates that data on VAT and CIT exhibited significant (strong) impact on Nigeria's growth. Given this outcome, the very need for the country to expand her tax net while simultaneously embarking on tax sensitization campaigns that will promote deliberate tax acquiescence by the teaming masses were recommended. Additionally, the study suggested the reinforcement of existing tax management systems in Nigeria as the current system appears to be largely deficient. In this vein, the study equally harped on why relevant tax directorates should engage qualified tax practitioners to efficiently administer the approved tax regime.

Takumah [27] conducted a Ghanaian study which investigated the causal link between tax proceeds and Ghana's economic growth. Utilizing quarterly data spanning 1986-2010 and with the aid of the Vector Autoregressive analysis, the research reported the existence of long co-integrating association among GDP, foreign direct investment, tax revenue, consumer price index, gross fixed capital formation, government expenditure and labour force. Also, other evidence from the study's outcome suggests that Ghana's economic growth and tax proceeds exhibit both long and short run association. The study therefore recommends the expansion of possible tax collection techniques by strategically reducing tax rates or by expanding the tax base with a view to boosting Ghana's internal revenue base.

Olayungbo and Olayemi [19] investigated the causal relationships between government expenditure, economic growth and non-oil income in Nigeria and data for 35 years (1981-2015) were examined. The study which was poised to establish if there was any long-run association between the variables, utilized the error correction model to examine the impulse responses among identified variables. Additionally, the Granger Causality Test (GCT) amongst others was employed to conduct further analyses. Observably, the ensuing outcomes indicated that government's spending adversely influenced economic growth. Also, while non-oil income positively impacted significantly on government spending, its impact on Nigeria's economic growth was negative. Results from the GCT further confirm that non-oil income triggered government spending, yet its effect on economic growth was insignificant thus corroborating the tax-spending hypothesis advocated by the Keynesians. Among the recommendations made was that the country should focus on economic diversification beyond oil through a conscious and committed expansion of the country's industrial sector.

\section{Methodology}

The non-experimental design tends to examine the level of significance of the relationship and/or cause-effect of changes among variables. Thus, the non-experimental design was considered appropriate and useful in understudying a causality analysis of non-oil tax component of government revenue, company income and transaction taxes by obtaining empirical evidence form a third world developing economy - Nigeria. Our choice of design is further justified by its application by prior studies $[15,21,7,26,12]$. The data for this study (non-oil internally generated/tax revenue, CIT, Stamp duties) were collected from secondary sources and covered 16 year period $-2000-2015$. The data were sourced from the publications of the Federal Inland Revenue Services (FIRS), and the CBN statistical bulletin.

The first step adopted for this analysis is the test of stationary (Unit root test), to ascertain the stationarity status of the data in order to avoid spurious results. Others test conducted include the granger causality test which according to Granger [9] is useful in determining whether 
the selected independent variables could clearly predict the dependent variable. Similarly, the Chow test which tests the structural stability or effect of identified policies on the trend or behaviour of variables was expressly employed to determine if the selected tax reforms have significantly improved the federally generated internal revenue in Nigeria. Just as this present study, a series of data can contain a structured break for instance, CITA is 2007 (7 years pre and 8 years post reform period) while the breakpoint in SDA is 2004 (4 years pre and 11 years post reform period).

The model is thus specified as:

$$
\begin{aligned}
& I G R=f(C I T) \\
& I G R=f(S D)
\end{aligned}
$$

Stating the explicit stochastic form of equation 1 and 2;

$$
\begin{gathered}
I G R=\delta_{0}+\delta_{1} C I T+\varepsilon_{t} \\
I G R=\lambda_{0}+\lambda_{1} S D+\varepsilon_{t}
\end{gathered}
$$

Where

$I G R=$ Federal Non-oil Internal Generated Revenue $C I T$ = Company Income Tax

$$
\begin{aligned}
& S D=\text { Stamp Duty Tax } \\
& \varepsilon_{t}=\text { Error Term }
\end{aligned}
$$

Table 2 however showcases the nomenclature and definitions of the variables along with their labels and measurements.

\section{Results and Discussions}

The summary of the unit root test is shown in the table 3.

The result from Table 3 shows that company income tax is stationary at level, which implies that they are integrated at order zero, I (0), while stamp duty tax and federal non-oil generated revenue is not stationary at level, implying that it has a random walk. Data for the variables were therefore subjected to test for unit roots at $1^{\text {st }}$ difference (see Table 4).

\begin{tabular}{|c|c|c|c|}
\hline Variables & Labels & Definitions & Measurement \\
\hline $\begin{array}{l}\text { Company Income } \\
\text { Tax }\end{array}$ & CIT & $\begin{array}{l}\text { These are direct taxes imposed on companies by governments of } \\
\text { identifiable jurisdictions. The taxes are usually levied on companies' } \\
\text { incomes. }\end{array}$ & (N'Billions) \\
\hline Stamp Duty & SD & $\begin{array}{l}\text { A tax on legal documents such as those used, e.g., for the sale or purchase of } \\
\text { shares or the conveyance of a property to a new owner }\end{array}$ & (N'Billions) \\
\hline $\begin{array}{c}\text { Non-oil Tax } \\
\text { Revenue/Non-tax } \\
\text { receipts }\end{array}$ & IGR & These are government revenue not generated from petroleum profit taxes. & (N'Billions) \\
\hline
\end{tabular}

The result from Table 4 shows that CIT, Stamp Duty tax and federal non-oil generated revenue are stationary at first difference, which implies that they are integrated at order one, I(1).

Table 2. Definition of Variables

Source: Compiled by Authors

Table 3. The Unit Root Test Result for the Selected Variables (at Levels)

\begin{tabular}{ccccccc}
\hline & $\begin{array}{c}\text { ADF } \\
\text { (at level) }\end{array}$ & $\mathbf{1 \%}$ & $\mathbf{5 \%}$ & $\mathbf{1 0 \%}$ & Summary & $\begin{array}{c}\text { Order of } \\
\text { Integration }\end{array}$ \\
\hline CIT & 9.424 & -2.728 & -1.966 & -1.605 & Stationary & I $(0)$ \\
SD & -3.224 & -4.728 & -3.759 & -3.324 & Non-Stationary & - \\
Non-oil IGR & 2.336 & -3.959 & -3.081 & -2.681 & Non-Stationary & - \\
\hline
\end{tabular}

Source: Researchers' computation, 2020

Table 4. The Unit Root Test Result for the Selected Variables (at $1^{\text {st }}$ Difference)

\begin{tabular}{cccccc}
\hline Variable & ADF Statistic & $\mathbf{1 \%}$ Critical value & $\mathbf{5 \%}$ Critical value & $\mathbf{1 0 \%}$ Critical value & $\begin{array}{c}\text { Order of } \\
\text { integration }\end{array}$ \\
\hline CIT & -4.291 & -2.754 & -1.970 & -1.603 & $1(1)$ \\
SD & -5.715 & -4.800 & -3.791 & -3.342 & $1(1)$ \\
Non-oil IGR & -5.885 & -4.057 & -3.119 & -2.701 & $1(1)$ \\
\hline
\end{tabular}

Source: The Researcher's Computation Using E-views 7.1 
Table 5. Descriptive Analysis of CIT, PIT, SD, VAT and Non-Oil IGR:

\begin{tabular}{cccc}
\hline & D(CIT) & D(SD) & D(NON_OIL IGR) \\
\hline Mean & 88.746 & 0.446 & 155.393 \\
Maximum & 220.000 & 3.300 & 347.100 \\
Minimum & 16.000 & -3.800 & 30.000 \\
Std. Dev. & 67.868 & 1.483 & 100.641 \\
Skewness & 0.621 & -1.085 & 0.578 \\
Kurtosis & 2.103 & 6.339 & 2.272 \\
Jarque-Bera & 1.468 & 9.917 & 1.166 \\
Probability & 0.479 & 0.007 & 0.557 \\
Observations & 16 & 16 & 16 \\
\hline
\end{tabular}

Source: Researchers' computation, 2020

Table 6. Results of Granger causality tests of selected variables

\begin{tabular}{cccc}
\hline Null Hypothesis: & Obs & F-Statistic & Prob. \\
\hline CIT does not Granger Cause Non-oil IGR & 16 & 0.120 & $0.037^{* *}$ \\
Non-oil IGR does not Granger Cause CIT & & 0.599 & 0.569 \\
SD does not Granger Cause Non-oil IGR & 16 & 0.258 & $0.041^{* *}$ \\
Non-oil IGR does not Granger Cause SD & & 20.535 & 0.050 \\
\hline
\end{tabular}

Source: Researchers' computation, 2020

Table 7. Regression Result of CIT against Total Non- oil IGR

\begin{tabular}{|c|c|c|c|c|}
\hline \multicolumn{5}{|c|}{$\begin{array}{l}\text { Dependent Variable: TOTAL_NON_OIL IGR } \\
\text { Method: Least Squares } \\
\text { Sample: } 20002015 \\
\text { Included observations: } 16\end{array}$} \\
\hline Variable & Coefficient & Std. Error & t-Statistic & Prob. \\
\hline $\mathrm{C}$ & 85.805 & 44.081 & 1.946 & 0.071 \\
\hline CIT & 1.895 & 0.068 & 27.756 & 0.000 \\
\hline R-squared & 0.982 & \multicolumn{2}{|c|}{ Mean Dep. Var.. } & 1028.356 \\
\hline Adjusted R-squared & 0.980 & \multicolumn{2}{|c|}{ S.D. Dep. Var. } & 813.042 \\
\hline S.E. of Regress. & 112.430 & \multicolumn{2}{|c|}{ Akaike Info. Criter. } & 12.399 \\
\hline Sum -squared Resid. & 176969.0 & \multicolumn{2}{|c|}{ Schwarz Criter. } & 12.495 \\
\hline Log likelihood & -97.192 & \multicolumn{2}{|c|}{ Hannan-Quinn Criter. } & 12.403 \\
\hline F-Stat. & 770.420 & \multicolumn{2}{|c|}{ Durbin-Watson Stat. } & 0.804 \\
\hline Prob(F-statistic) & 0.000 & & & \\
\hline
\end{tabular}

Source: Researchers' computation, 2020

The standard deviations of the operational data chosen are $67.86 \%, 1.48 \%$ and $101 \%$ for Company income tax, Stamp Duty tax and federal non-oil generated revenue respectively. Apart from the total non-oil revenue, other variables recorded standard deviations that were less than 100. The skewness and Kurtosis are contained in Jarque_Bera. Jarque_bera is used to test for normality; to know whether data are normally distributed. Jarque_Bera theory posits that, if probability value is less than $10 \%$ we accept the alternate $\left(\mathrm{H}_{\mathrm{I}}\right)$ meaning that the data follows a normal distribution, otherwise, accept the null, meaning that they are not normally distributed. In this case, the respective prob. values are 0.479 for CIT, 0.007 for SD and 0.557 for total non oil revenue, thus implying that they are normally distributed since the p-values are less than $10 \%$.

Table 6 unveils a summary result of the granger causality estimates which suggests that a uni-directional relationship exists between CIT and total non-oil IGR with probability values below $10 \%$ significant level. This implies that CIT in the long run contributes/triggers significant change to total non-oil revenue component for the Nigerian economy. Also, stamp duty (SD) shows a uni-directional relationship with non-oil IGR. This implies that SD contributes significantly to non-oil revenue.

We ran the regression model by taking CIT and federal non-oil internally generated revenue (IGR) in Nigeria (2000-2015) as explanatory variable and explained variable respectively. The Ordinary Least Square estimates suggest that there is a positive linear and 
significant relationship between CIT and non-oil revenue with coefficient value of 1.895 . This implies that each unit change in CIT triggers 1.89 percent increase in non-oil revenue. The result shows an auto-regression problem as shown by the Durbin-Watson of 0.804 . An auto-regressive method was used to correct this as shown on table 8 .

The result in Table 8 shows an $\mathrm{R}^{2}$ of 0.99 indicating a predictive ability of CIT on Total non-oil revenue at 99\%. While regression coefficient (coeff.) has a positive statistically insignificant beta weight of .977 or $97.73 \%$; $\mathrm{p}=.0 .119$. The Durbin-Watson has been corrected with a value of 1.758015 which falls within 1 to 3 . Additionally, the F-statistics of 647.263 (prob $=0.000$ ) shows a significant relationship between non-oil revenue and CIT.

However, since the hypothesis is to test the effect CIT on federal non-oil tax IGR in Nigeria, the chow test was done after carrying out a pre and post reform regression model analysis. Based on the Chow-test computed in Table 9 there is no significant difference in model effect, that is, there is no structural change in the reform since the calculated value of 2.416 as shown in table 9 is lower than the F-distribution table of 3.862548 at $\mathrm{F}(2,12)$. We therefore accept the null hypothesis (Ho) and reject the alternate hypothesis $\left(\mathrm{H}_{1}\right)$ and conclude that the models are the same, that is, there is no significant structural change in pre and post implementation of CITA reform on federal non-oil IGR in Nigeria.

This therefore indicates that CIT Act of 2007 has not impacted significantly on non-oil revenues in Nigeria. Consequently, the null hypothesis suggests that the CITA's implementation has not significantly improved federal IGR in Nigeria is sustained and not rejected.

Table 8. Auto Regressive Corrective Regression Model Result of CIT against federal Non- oil IGR

\begin{tabular}{|c|c|c|c|c|}
\hline \multirow{2}{*}{\multicolumn{5}{|c|}{$\begin{array}{l}\text { Dependent Variab: TOTAL_NON_OIL IGR } \\
\text { Method: Least Squares } \\
\text { Convergence achieved after } 76 \text { iterations }\end{array}$}} \\
\hline & & & \multicolumn{2}{|c|}{ Convergence achieved after 76 iterations } \\
\hline Variable & Coeff. & Std. Err. & t-Stat. & Prob. \\
\hline $\mathrm{C}$ & 16023.50 & 370896.2 & 0.043 & 0.966 \\
\hline CIT & 0.977 & 0.582 & 1.677 & 0.119 \\
\hline $\mathrm{AR}(1)$ & 0.995 & 0.103 & 9.629 & 0.000 \\
\hline R-squared & 0.990 & \multicolumn{2}{|c|}{ Mean Dep. Variab. } & 1088.860 \\
\hline Adjusted R-squared & 0.989 & \multicolumn{2}{|c|}{ S.D. Dep. Variab. } & 803.430 \\
\hline S.E. of regression & 83.167 & \multicolumn{2}{|c|}{ Akaike info. Criter } & 11.856 \\
\hline Sum squared resid. & 83001.76 & \multicolumn{2}{|c|}{ Schwarz Criter. } & 11.998 \\
\hline Log likelihood & -85.923 & \multicolumn{2}{|c|}{ Hannan-Quinn Criter. } & 11.854 \\
\hline F-statistic & 647.263 & \multicolumn{2}{|c|}{ Durbin-Watson Stat. } & 1.758 \\
\hline Prob(F-statistic) & 0.000 & & & \\
\hline
\end{tabular}

Source: Researchers' computation, 2020

Table 9. Chow Test Result between CIT (2007) and Non-oil IGR

\section{Chow Breakpoint Test: 2007}

Null Hypothesis: No Breaks at Spec. Breakpoints

Varying-Regressors: All Eqn. Variab.

Eqn. Sample: 2000- 2015

$\begin{array}{cccr}\text { F-Stat. } & 2.416 & \text { Prob. F(2,12) } & 0.131 \\ \text { Log Likelihood Ratio } & 5.414 & \text { Prob. Chi-Square(2) } & 0.066 \\ \text { Wald Stat. } & 4.832 & \text { Prob. Chi-Square(2) } & 0.089\end{array}$

Source: Researchers' computation, 2020 
Table 10. Regression result of SD against non-oil IGR

\begin{tabular}{|c|c|c|c|c|}
\hline \multicolumn{5}{|c|}{$\begin{array}{l}\text { Dep. Variab: TOTAL_NON_OIL IGR } \\
\text { Method: Least-Squares } \\
\text { Sample: } 2000 \text { - } 2015 \\
\text { Included obs.: } 16\end{array}$} \\
\hline Variable & Coefficient & Std. Error & t-Statistic & Prob. \\
\hline $\mathrm{C}$ & 71.588 & 97.602 & 0.733 & 0.475 \\
\hline SD & 236.239 & 18.927 & 12.481 & 0.000 \\
\hline R-squared & 0.917 & \multicolumn{2}{|c|}{ Mean Dep. Var. } & 1028.356 \\
\hline Adjusted R-squared & 0.911 & \multicolumn{2}{|c|}{ S.D. dep. Var. } & 813.042 \\
\hline S.E. of regression & 241.663 & \multicolumn{2}{|c|}{ Akaike Info. Criter. } & 13.929 \\
\hline Sum-Squared resid & 817619.1 & \multicolumn{2}{|c|}{ Schwarz Criter. } & 14.026 \\
\hline Log likelihood & -109.435 & \multicolumn{2}{|c|}{ Hannan-Quinn Criter. } & 13.934 \\
\hline F-Stat. & 155.783 & \multirow{2}{*}{\multicolumn{2}{|c|}{ Durbin-Watson (DW) Stat. }} & 2.017 \\
\hline Prob(F-statistic) & 0.000 & & & \\
\hline
\end{tabular}

Source: Researchers' computation, 2020

Table 11. The Chow Test Result between SD Act 2004 and Non-oil IGR

Chow Breakpoint Test: 2004
Null Hypothesis: No breaks at specified breakpoints
Varying Regressors: All equation variables
\begin{tabular}{cccc} 
Equation Sample: 2000 2015 & & & \\
\hline F-statistic & 0.066 & Prob. F(2,12) & 0.936 \\
Log likelihood ratio & 0.175 & Prob. Chi-Square(2) & 0.916 \\
Wald Stat. & 0.132 & Prob. Chi-Square(2) & 0.936 \\
\hline
\end{tabular}

Source: Researchers' computation, 2020

The regression model is run by taking Stamp Duty and federal non-oil IGR in Nigeria (2000-2015) as independent variable and explained variable respectively. The regression model result in table 10 shows an $\mathrm{R}^{2}$ of $91.75 \%\left(\mathrm{R}^{2}=.0 .917\right)$ showing that the SD can predict IGR to the value of $91.75 \%$. With regression coefficient (SD) has a positive statistically significant beta weight of 236.239; $\mathrm{p}=.0000$. Also the DW-Stat. is 2 showing that there is no autocorrelation. The F-value shows a very significant relationship between $\mathrm{SD}$ and the total non-oil revenue; the pooled regression model is statistically significant $\left.\mathrm{F}(2,14)=155.7833, \mathrm{R}^{2}=.9175 ; \mathrm{p}=.000\right)$.

We additionally examined the effect of Stamp Duty on federal non-oil IGR in Nigeria. This is shown in the summarized chow test result (see Table 11) after carrying out a pre and post reform regression model analysis. Based on the Chow-test computed in Table 11, the obvious is that there is no significant difference in the models effect, that is, there is no structural change in the reform since the calculated value as shown in Table 11 is 0.066 which is less than the F-distribution table of 3.885. We therefore accept the null hypothesis (Ho) and reject the alternate hypothesis $\left(\mathrm{H}_{1}\right)$ and conclude that the models are the same; that is, there is no significant structural change in pool, pre and post implementation of Stamp Duty reform Act 2004 on federal non-oil tax IGR in Nigeria. This therefore indicates that Stamp Duties has no significant impacts on the non-oil tax IGR in Nigeria. The null hypothesis is therefore sustained and not rejected.

Noticeably, the implementation of CITA has not significantly improved non-oil tax IGR of Nigeria as shown by the result of this study. This also is in contrast with the results of Madugba, Ekwe and Kalu [14] who found a positive and significant relationship between CIT and the country's Consolidated Revenue.

Finally, the study shows an insignificant impact on the implementation of Stamp Duties Act, 2004. As earlier pointed, the Nigerian Government which ought to be a continuum has failed in putting in place effective tax reforms that will rake in adequate income and stabilise the economy. The future of the Nigerian economy is blurred; the rich appears to be getting richer while the poor are getting poorer by each passing day. The gap between the poor and rich is widening by the day. This can be traced to poor fiscal policy and implementation.

\section{Conclusions and Recommendations}

Following the findings of the previous section, it was concluded that the implementation of the selected tax reforms has not significantly improved the federal non-oil internally generated revenue in Nigeria since at every instance, the F-statistic was always lower than the 
F-distribution. This therefore means that the major objective of tax reform which is to improve government IGR [16], was not achieved. Based on this premise, it is recommended that;

i. In order to significantly improve the non-oil tax revenues in Nigeria through company Income tax, the federal government should marginally reduce the tax holidays and incentives granted to companies in other to boost or get more tax revenue from the increased profit of companies.

ii. $\quad$ Effective policy pertaining to Stamp Duties should be put in place and there should be full implementation of the stamp duties act, 2004 vis-à-vis strict penalties for non-compliance. This will encourage compliance which will lead to improvement in revenue generation from stamp duties.

\section{REFERENCES}

[1] Adegbite T. A., "The Analysis of the Effect of Corporate Income Tax (CIT) on Revenue Profile in Nigeria," American Journal of Economics, Finance and Management, vol. 1, no. 4, pp. $312-319,2015$.

[2] Adeusi A. S., Uniamikogbo E., Erah O. D., Aggreh M., "Non-Oil Revenue and Economic Growth in Nigeria". Research Journal of Finance and Accounting vol. 11 no. 8, pp. 95-106, 2020. DOI: 10.7176/RJFA/11-8-10

[3] Agbeyegbe T. D., Stotsky J., Wolde Mariam A., “Trade liberalization, exchange rate changes, and tax revenue in Sub-Saharan Africa," Journal of Asian Economics, vol. 17, pp. 261-284, 2006. DOI:10.1016/j.asieco.2005.09.003.

[4] Anyaehie M. C., Areji A. C., "Economic diversification for sustainable development in Nigeria," Open Journal of Political Science, vol. 5, no.2, pp. 87 - 94, 2015.

[5] Baghebo M. "Effective utilization of tax revenue in Nigeria," International Journal of Academic Research in Business and Social Sciences," vol. 2, no. 7, pp. $280-289,2012$.

[6] Bird R. M., Zolt E. M., "Introduction to tax policy design and development," in Draft Document Prepared for a Course on Practical Issues of Tax Policy in Developing Countries, World Bank, 2003. https://gsdrc.org/document-1 ibrary/introduction-to-tax-policy-design-and-development/

[7] Engen E. M., Skinner J., "Taxation and Economic Growth," NBER Working Papers, No 5826, National Bureau of Economic Research, Inc, 1996.

[8] Etale L. M., Bingilar P. F., "The impact of Company Income Tax and Value-added tax on economic growth: evidence from Nigeria", European Journal of Accounting, Auditing and Finance Research, vol. 4, no. 7, pp. 106-112.

[9] Granger C. W. J., "Time series analysis, co-intergration and application," The American Economic Review, vol. 94, no. 3, pp. $421-425,2004$.

[10] Ihenyen C. J. Mieseigha E. G., "Taxation as an instrument of economic growth: The Nigerian perspective," Information and Knowledge Management, vol. 4, no. 12, pp. $49-53,2014$.

[11] Jeroh E., "Assessing the nexus between forensic accounting, the Finance Act, 2019 and tax revenue in Nigeria," Journal of Forensic Accounting and Fraud Investigation, vol. 4, no. 2, pp. 209 - 233, 2019.

[12] Kneller R., Bleaney M. F., Gemmell N., "Fiscal policy and growth evidence from OECD countries," Journal of Public Economics, vol. 74, no. 2, pp.171-190, 1999.

[13] Kusi N. K., "Tax reform and revenue productivity in Ghana," AERC Research Paper 74, African Economic Research Consortium, 1998.

[14] Madugba J. U., Ekwe M. C., Kalu J. M., "Corporate tax and revenue generation: Evidence from Nigeria," Journal of Emerging Trends in Economics and Management Sciences (JETEMS), vol. 6, no. 5, pp. 333-339, 2015.

[15] Nassar M. L. Fasina H. T. "Impact of personal income tax on internally generated revenue performance in Oyo state," International Journal of African Culture and Ideas, vol. 5, no. 1 , pp. 26-38, 2005.

[16] Nightingale K., "Taxation - Theory and Practice Updated For $2002-2004,4^{\text {th }}$ ed, Pearson Educational, 2001.

[17] Ofoegbu G. N., Akwu D. O., Oliver O., "Empirical analysis of the effect of tax revenue on economic development of Nigeria," International Journal of Asian Social Science, vol. 6, no.10, pp. $604-613,2016$.

[18] Olaoye C. O., Adebayo O. C., "Effect of Base Erosion and Profit Shifting on revenue generation in Nigeria", Universal Journal of Accounting and Finance, vol. 8, no. 1, pp. 21 -28, 2020. DOI: 10.13189/ujaf.2020.080102.

[19] Olayungbo D. O., Olayemi O. F., "Dynamic relationships among non-oil revenue, government spending and economic growth in an oil producing country: Evidence from Nigeria", Future Business Journal, vol. 4, no. 2, pp. 246-260, 2018. DOI: 10.1016/j.fbj.2018.07.002G.

[20] Oriakhi D. E., Ahuru R. R., "The impact of tax reform on federal revenue generation in Nigeria," Journal of Policy and Development Studies, vol. 9, no. 1, pp. 92 - 108, 2014.

[21] Patric H. H., "The Tax Reform Act of 1986 and Economic Growth," NBER Working Papers 2553, National Bureau of Economic Research, Inc., 1988.

[22] Pfister M., "Taxation for investment and development: An overview of policy challenges in Africa," Ministerial Meeting and Expert Roundtable of the NEPAD - OECD Africa Investment Initiative, November 11 - 12, 2009. https://www.oecd.org/investment/investmentfordevelopm ent/43966821.pdf.

[23] PWC, "A guide to stamp duties in Nigeria," 2020. https://www.pwc.com/ng/en/assets/pdf/a-guide-to-stamp-d uties-in-nigeria-2021.pdf.

[24] Soubbotina T. P. "Beyond Economic Growth an Introduction to Sustainable Development," WBI Learning Resources Series, World Bank Group, 2004.

[25] Soyode L. Kajola S. O., "Taxation Principles and Practice in Nigeria," Silicon Pub., 2006. 
[26] Steenekamp T., "The progressivity of personal income tax in South Africa since 1994 and directions for tax reform," Southern African Business Review, vol. 16, no. 1, pp. 39-57, 2012.

[27] Takumah W., "Cointegration and causality between tax revenue and economic growth in Ghana", International
Research Journal of Marketing and Economics, vol. 1, no. 6, pp. $30-44,2014$.

[28] Uzonwanne C. M., "Economic diversification in Nigeria in the face of dwindling oil revenue," Journal of Economics and Sustainable Development, vol. 6, no. 4, pp. 61 - 67, 2015. 